\title{
Symbiotic Anthropology and Politics in a Postmodern Age: Rethinking the Political Philosophy of Johannes Althusius (1557-1638)
}

\author{
NICO VORSTER
}

North-West University, South Africa

\begin{abstract}
Postmodern societies are increasingly characterized by a hyperpluralism that coincides with an interdependence between social spheres and structures. Actions in one sphere of life often impinge on other spheres of life. This leads to a consistent and endemic conflict between the social dynamics of plurality and the need for social unity. The symbiotic political theory of Johannes Althusius (1557-1638), which attempts to preserve unity through organized plurality, might be helpful in addressing the plurality/unity conundrum so characteristic of postmodern societies. Central to this approach are the anthropological and political notions of symbiosis, association, communication, and sharing. After providing some background to Althusius's thought, this article discusses his symbiotic anthropology and explicates his symbiotic political theory. The article concludes by identifying five features of Althusius's political theory that might be helpful to contemporary postmodern society.
\end{abstract}

Les sociétés postmodernes se caractérisent de plus en plus par un hyper-pluralisme ethnoculturel qui coïncide avec une dépendance mutuelle croissante entre diverses sphères et structures sociales. Ce qui se fait dans l'une de ces sphères a souvent un impact sur d'autres. Il en découle un conflit systématique et permanent opposant la dynamique sociale du pluralisme et le besoin d'unité sociale. La théorie politique symbiotique de Johannes Althusius (1557-1638), qui cherche à maintenir l'unité par l'organisation du pluralisme, permettrait d'affronter la contradiction unité/pluralisme qui marque tant les sociétés postmodernes. Cette approche est fondée sur les notions politiques et anthropologiques de symbiose, d'association, de communication et de partage. Dans cet article, après avoir présenté quelques prémisses de la pensée d'Althusius, on examine son anthropologie de la symbiose et on analyse sa théorie politique de la symbiose. On termine l'article avec l'identification de cinq traits de la théorie politique d'Althusius qui pourraient être utiles aux sociétés postmodernes d’aujourd'hui.

\section{Introduction}

Tost Western states address the age-old plurality/unity conundrum so 1 endemic to political discourse by separating the public and private realms as well as the profane and sacred spheres. In doing so, it is believed that conflicts between various social spheres can be limited and that some kind of hegemony can be enforced on society. In postmodern society, such 
separation becomes difficult because societies are increasingly characterized by a hyperpluralism that coincides with a pervasive interconnectedness between various social spheres.

Lemert ${ }^{1}$ ascribes the rise of the postmodern society in the Western world to the sudden collapse of the Euro-American colonial system, the defeat of communism, and a rising opposition to the notion of a universal world culture. The postmodern resistance to universal political and social metanarratives contributed, among other things, to what Brad Gregory calls an "extraordinary pluralism" in modern societies. ${ }^{2}$ This hyperpluralism is characterized by diversity, individualism, social differentiation and privatization, the open-endedness of moral narratives, and a general lack of a sense of belonging and identity. Charles Taylor speaks of a trend of "fragilization": "The existence of an alternative fragilizes each context. This fragilization is then increased by the fact that great numbers of people are not firmly imbedded in any such context, but are puzzled, cross-pressured or have constituted a bricolage of median position."3

Ironically, the hyper-plural diversity of the postmodern age coincides in modern societies with the inescapable interdependence of social spheres, structures, and spaces. The causal nature of the global political and economic system is such that modern societies are prone to experience domino effects when things go wrong in one segment of a society. Elazar rightly notes that in postmodern societies "everything impinges upon everything else, making sharing more necessary."4 Postmodern society, in fact, has evolved into a highly complex, diverse, technological, and interrelated phenomenon that requires renewed reflection on political and social organization.

Within this new political and social context the political theory of Johannes Althusius deserves attention. The main aim of Althusius's political theory was to address the plurality/unity conundrum of his time. ${ }^{5}$ The Reformation

1. Charles Lemert, Postmodernism Is Not What You Think (Oxford: Blackwell, 1997), 32-33.

2. Brad Gregory, The Unintended Reformation: How a Religious Revolution Secularized Society (Cambridge, MA: Belknap Press), 4.

3. Charles Taylor, A Secular Age (Cambridge, MA: Belknap Press, 2007), 556.

4. Daniel J. Elazar, “Althusius' Grand Design for a Federal Commonwealth," in Politica, trans. and ed. Frederich S. Carney (Indianapolis: Liberty Fund, 1964), xlvii-lvii, xlv.

5. For a good discussion on the historical factors that inspired Althusius to develop his political theory see Thomas O. Hueglin, Classical Debates for the 21 ${ }^{\text {st }}$ Century: Rethinking Political Thought (Ontario: Broadview Press, 2008). 
brought about factionalism, schisms, and instability in seventeenth-century European societies, which generated a radical counter response. Jean Bodin (1520-96), for instance, proposed that order be restored in European societies by vesting the sovereignty of the state in a monarchy whose power is limited only by natural and divine law, not civil or positive law. ${ }^{6}$ Althusius's Politica vigorously defended the autonomy of the plural orders of his time against the rise of absolutism. In response to Bodin, Althusius defined politics not as the exercise of absolute power, but as the art of associating. Conversely, in reaction to the factionalism that the Reformation caused, he emphasized the importance of strong rule.

The aim of this article is to assess the relevance of Althusius's symbiotic political theory for addressing the pluralist/unity conundrum that is so endemic to postmodern societies. The central argument is that constitutionalism cannot be developed merely on the premises of a separation of social spheres and the protection of individual rights in order to limit the power of the state. Such a one-sided approach is prone to fragmenting the commonwealth and disenfranchising minority groups, because it is so strongly connected with the concept of individualism that it cannot deal with problems of community and diversity. What is needed is a brand of constitutionalism that creates political space for intermediate civil institutions that can act as mediators between the interests of the state and individuals. Althusius's notions of symbiosis, association, communication, and sharing are of considerable import in a postmodern era, because they allow us to preserve unity through an organized plurality.

\section{Historical setting}

Althusius (1557-1638) was a political philosopher and jurist who emerged from the orthodox Calvinist tradition during the transitional period between the medieval and modern epochs. According to John Witte, his work "helped to integrate" Dutch social, legal, and political thought and "served to elaborate an emerging Calvinist theory of natural law, popular sovereignty and the rights and liberties of individuals and associations." Althusius studied in Geneva,

6. See Stephen J. Grabill, "Introduction," in Selections from the Dicaelogicae, trans. Jeffrey J. Veenstra, Journal of Markets and Morality 9.2 (2006): 403-429, 405.

7. John Witte, The Reformation of Rights: Law, Religion and Human Rights in Early Modern Calvinism (Cambridge: Cambridge University Press, 2007), 150. 
Basel, and Cologne and eventually attained his doctoral degree, both in canon and civil law, at the University of Basel in 1586. During the same year he was appointed as professor at the Calvinist University of Herborn where he ultimately became rector. In 1604 he was appointed as city syndic of Emden, a seaport in north-western Germany and an important trade centre in Europe. Emden was a refuge for Dutch Calvinists and is often called the "Geneva of the North." ${ }^{8}$ During his stay in Emden he presented his political philosophical thought in his classic work Politica Methodice Digesta, first published in 1603 and expanded in 1610 and $1614 .{ }^{9}$ He also wrote a work on law entitled Dicaeologica libri tres (1617).

Though Althusius acquired his political insights from a variety of sources, Otto Von Gierke is correct when he states that Althusius's political theory was built on and informed primarily by a religious worldview. ${ }^{10}$ His political philosophy arose from the political and theological climate of the Reformation in Germany, the Netherlands, Switzerland, and France and strongly resembles the Calvinist and Presbyterian understanding of the church polity as a decentralized entity constructed from lower assemblies to higher assemblies. The Reformed biblical notion of covenant also plays a foundational role in his societal doctrine. In Politica Althusius specifically attempted to limit the spread of centralized monarchies by developing a theory of symbiotic association that gave concrete and practical content to the Reformed Protestant understanding of the polity. He expounded his system by synthesizing political theories found within the Holy Roman Empire with the Reformed understanding of covenant

8. See Thomas Hueglin, “Johannes Althusius: Medieval Constitutionalist or Modern Federalist?” Publius 9.4 (Autumn, 1979): 9-41, 17.

9. This article uses the 1961 facsimile Latin edition of Althusius's work published by Scientia Verlag: Johannes Althusius, Politica Methodice digesta atque exemplis facris \& profanis illustrata (Aalen: Scientia Verlag, 1961). References to this work will mention the chapter and the paragraph number: for example, 1.27 .

10. Otto Von Gierke, Johannes Althusius und die Entwicklung der naturrechtlichen Staatstheorien (Aalen: Scientia Verlag, 1968), 56. Althusius himself was a Calvinist and he often refers to Calvin in his Politica. Althusius specifically utilized Calvin's doctrine of society as a neighbourhood, Calvin's understanding of gifts, and Calvin's view on the relation between church and state. Most importantly, he borrowed from Calvin the notion of society as a series of social pacts that emanate from the foundational pact of marriage. Lastly, Althusius's understanding of the relationship between higher and lower forms of government was influenced by the Calvinist system of church government that originated at the Synods of Wesel (1568) and Emden (1571). 
theology. ${ }^{11}$ Whereas philosophers of the Enlightenment used methodological individualism to construct their political theories, Althusius's point of departure was the symbiotic nature of the human being who seeks relationships and enters into covenants in order to lead a sustainable life.

Althusius employed the logical method of Peter Ramus (1515-1572), an accomplished French logician, to organize his works. His books were structured on the two principles of Ramusian logic, namely invention and disposition. ${ }^{12}$ Invention entailed determining what subject matter belongs to a topic, while disposition concerned the method of organizing a discipline in an orderly fashion. ${ }^{13}$ Althusius vigorously defended the sovereignty of the various sciences and attempted to refrain from unnecessarily mixing the discipline of politics with jurisprudence or theology. ${ }^{14} \mathrm{He}$ nevertheless maintained that political science had the right to share the insights of the Decalogue with theology, because social life cannot do without the Decalogue. ${ }^{15}$ Although theology cannot be used to construct political science, he nevertheless believed that theology serves as an important preamble to political science, because political science depends on theology. ${ }^{16}$

\section{Human nature as symbiotic}

As can be seen from the first chapter of the Politica, Althusius attempted to arrange society according to human nature. Thomas Hobbes also followed this approach, but their views on the essential nature of human personhood diverged. Whereas Hobbes defines humans as basically self-interested beings who "have a

11. Daniel J. Elazar, “The Multi-faceted Covenant: The Biblical Approach to the Problem of Organizations, Constitutions, and Liberty as Reflected in the Thought of Johannes Althusius," Constitutional Political Economy 2.2 (1991): 187-208, 192.

12. Frederich Carney, The Associational Theory of Johannes Althusius: A Study in Calvinist Constitutionalism (Chicago, IL: Chicago University Press, 1960), 27.

13. Carney, Associational Theory, 23-24.

14. Stephen J. Grabill, Rediscovering the Natural Law in Reformed Theological Ethics (Grand Rapids, MI: Eerdmans, 2006), 130.

15. Carney, Associational Theory, 29.

16. Carney, Associational Theory, 31. 
perpetual and restless desire of power after power," ${ }^{17}$ Althusius regards humans as essentially social beings naturally attached to God and fellow human beings and therefore born to live in community and to cultivate society. ${ }^{18} \mathrm{God}$, after all, created human beings with "an instinct for living together and establishing society." ${ }^{19}$ No human being is self-sufficient. When born, humans are destitute and defenceless. Even as adults, we cannot show forth the light of reason on our own. As long as we do not mingle with society we cannot live a fruitful life. We need a symbiotic kind of life in order to be comfortable and to realize ourselves as human beings. ${ }^{20}$ Althusius consequently describes the human being as a "civil animal who strives eagerly for association." ${ }^{21}$ Importantly, for Althusius symbiosis (living together) entails more than merely a common existence; it "indicates a quality of mutual sharing and communication" without which society is not possible. ${ }^{22}$ This normative use of the concept of symbiosis is unique to Althusius. Yet, the concept itself finds its origins in a combination of Calvinist societal doctrine that viewed society as a neighbourhood where individuals serve each other through their gifts, and the Aristotelian theory on symbiotic existence. ${ }^{23}$ This combination in Althusius's thought is not surprising, since Calvinism relied heavily on Aristotelian categories in its doctrines on the relation between God, creation, and humanity. ${ }^{24}$

17. Thomas Hobbes, Leviathan or the matter, forme and power of a Commonwealth Ecclesiastical and Civil (Oxford: Blackwell, 1946), 64.

18. Althusius, Politica, 1.27 .

19. Althusius, Politica, 1.33 .

20. Althusius, Politica, 1.3, 1.6.

21. Althusius, Politica, 3.33. See in this regard John Calvin's commentary on Genesis, in Ioannis Calvini opera quae supersunt Omnia (vols. 1-59), in Corpus Reformatorum, ed. Eduard Baum, Johan Wilhelm Reuss, and Eduard Wilhelm Eugen (Brunsvigae: C.A Schwetscke, 1863), 23:45, where he discusses the neighbourly nature of society. He regards the initial pact between husband and wife as a model for social pacts in other spheres of society. The Calvin Opera volumes are referenced as CO with notice of the relevant volume and page. Also see John Calvin, Sermons on Gen 1-11, translated by R. R. McGregor (Edinburgh: Banner of Truth Trust, 2009), 180, 181 191, 193. The original texts are in the Supplementa Calviniana series 11/1.125, 132, 135.

22. Carney, Associational Theory, 49.

23. Carney, Associational Theory, 180.

24. Calvin for instance made use of Aristotle's distinction between relative and absolute necessity, as well as his two-causes argument to explain how God could will the Fall without being the Author of the Fall. See CO 2:152 and 6:255. 
A second inborn feature of the human being, closely related to social nature, is the natural receptivity for the law of God. The human being is a moral being, because God has implanted in all human beings a natural understanding of the lex communis which enables us to have a fundamental understanding of right and wrong: "By the knowledge imprinted within us by God, which is called conscience, man knows and understands law and the means to be employed or avoided for maintaining obedience to law"25; and "Through this innate receptivity to God's law, human beings are able to perform acts of justice and to be good citizens."26

Althusius stresses that an adequate symbiosis in public life depends on an attitude of neighbourliness. God, after all, created human beings, both as loving creatures who need love and extend love and as communicative beings that develop forms of interaction and sharing. ${ }^{27}$ Marriage is for Althusius a prime example of the created neighbourly nature of the human being. Husband and wife are "symbiotically joined individuals" and become one in body and spirit through mutual assistance. ${ }^{28}$ The norms for a neighbourly life are expressed by the second table of the Decalogue, which advises us to seek the interests of our fellow human beings, often at the expense of our own rights. Human beings are not born to themselves; their country and friends have the right to claim a share in their lives. A human being who is not willing to share his gifts and services with the commonwealth has no value for society. ${ }^{29}$

Although all human beings are equal in terms of rights, they are not equal with regard to ability and gifts. ${ }^{30}$ God makes social symbiosis possible by investing human beings with a diverse range of gifts and with the ability to bond

25. Translation is from Johannes Althusius, Politica: An Abridged Translation of Politics Methodically Set Forth and Illustrated with Sacred and Profane Examples, trans. and ed. Frederick S. Carney (Indianapolis, IN: Liberty Fund, 1964), 139-40. For the original Latin see Althusius, Politica, 21.20: "Ex notitia a Deo impressa, quae conscientia dicitur, homo cognoscit \& intelligit ius \& media, seu facienda vel omittenda, quibus juri huic obedientia praestatur."

26. Althusius, Politica, 21.20.

27. See Witte, 182.

28. Bettina Koch, "Johannes Althusius: Between Secular Federalism and the Religious State," in The Ashgate Research Companion to Federalism, ed. Anne Ward and Lee Ward (Surrey: Ashgate, 2009), 75-90, 77.

29. Althusius, Politica, 1.27 .

30. See Koch, 87. 
and associate with other people. He does not distribute his gifts equally among all people, but he varies the distribution of gifts so that people are dependent on each other's gifts for survival. Difference in ability is in Althusius's thought a necessary precondition for an orderly society because it makes people dependent on each other and enables some people to govern, while others are governed. This varied distribution of gifts facilitates a need for communicating necessary and useful things. ${ }^{31}$ Since this need can only be addressed in social and political life, humans are compelled to set up institutions through a communication (exchange) of gifts and mutual agreements that cultivate and conserve a symbiotic life. ${ }^{32}$ Hence the common feature of all associations, from the most basic to the most universal, is that symbiosis determines their fundamental character. Of paramount importance in social life is vocation. Private persons need to take up their responsibilities in society according to the gifts they received from God. ${ }^{33}$

For Althusius society is about mutual aid, since the commonwealth is nothing else but a public body of persons that assist each other by devoting themselves to the "general good and welfare of this body." ${ }^{44}$ Given that mutual aid is the core business of social life, the efficient cause of political association is consent and agreement, the formal cause is a communication of things useful and necessary, while the enjoyment of life is the final cause. ${ }^{35}$ Frederich Carney rightly notes that association contains for Althusius a balance of necessity and volition. The diversity of God-given gifts makes the communication of gifts necessary, while the association is simultaneously maintained by consent and common agreement. ${ }^{36}$

Althusius grounds his notion of authority and submission in the created nature of the human body, which serves as a microcosmic image of what ought to happen in the political realm. The relations in the commonwealth correspond to the relation between the mind and the physical body:

\section{Althusius, Politica, 1.26.}

32. Althusius, Politica, 1.27.

33. See Carney, Associational Theory, 185.

34. Althusius, Politica, 1.27.

35. Althusius, Politica, 1.30.

36. Frederich S. Carney, "Translators Introduction," in Politica: An Abridged Translation of Politics Methodically Set Forth and Illustrated with Sacred and Profane Examples, ed. Frederick S. Carney (Indianapolis, IN; Liberty Fund, 1964), ix-xxxiii, xvi. 
Just as the mind reveals and performs all its actions in one physical body by the joining together and concord of its members, and unifies these members under one spirit, so also one imperium under the power of one person or a united group directs and rules in the commonwealth for the convenience of the members, declares laws, seeks the things necessary for human society, communicates concord and makes it firm and directs actions and friendships by suitable rules that either nature or necessity recommends should be kept inviolate. ${ }^{37}$

As God determined that the soul dominate the body and the mind the appetites, it is an inborn feature of human personhood that the powerful dominate and rule weaker men, just as it is an inborn characteristic of weaker men to submit to the rule of the stronger. ${ }^{38}$ As will be shown later, this understanding of human nature determines Althusius's understanding of government as consisting of imperium and subjection.

\section{The nature of politics}

For Althusius, politics is about the ordering of social life in all its plural forms through the process of association, which he terms "symbiotics." 39 Institutions exist as a means of fostering the symbiotic relationship between human beings that enables the community to live together. Althusius states it thus:

Politics is the art of associating (consociandi) men for the purpose of establishing, cultivating and conserving social life among them. Whence it is called "symbiotics." The subject matter of politics is therefore association (consociatio), in which the symbioses pledge themselves each to the other,

37. Translation from Carney, Politica, 96. For original Latin see Althusius, Politica, 18.21: "Nam quemodum in uno corpore physicom broru concordia \& colligatione mens actiones omnes suas exerit \& perfecit, \& unico spiritu eadem membracolligat, ita \& unum imperium cum potestate unius, vel plurium unitorum, in Rep. regit \& imperat membris convenientia \& legis dicit, concordiam firmat, \& humanae focietati necesaria exsequitur, communicat concordia, actiones \& amicias onvenientis. preaceptis regit, quae vel natura, vel necessitas suadet per se inviolata conservare.”

38. Althusius, Politica, 1.38 .

39. See Elazar, “The Multi-faceted Covenant," 196. 
by explicit or tacit agreement, to mutual communication of whatever is useful and necessary for the harmonious exercise of mutual life. ${ }^{40}$

Symbiosis involves more than merely co-existing; it depicts a process of sharing, communal problem solving, and mutual aid among the symbiotes that is guided by piety and justice. Althusius defines this activity of sharing as a communication of things (rerum), services (operarum), and rights (juris). ${ }^{41}$ The communication of things entails the "bringing of useful and necessary goods" to social life for the common benefit of all symbiotes, while the communication of services entails that symbiotes contribute to social life through their labour and occupational outputs. The communication of rights is the process whereby symbiotes organize their "common life" around a set of just rules. ${ }^{42}$ Given that communication is essential to human society, human society is constructed from below by a series of pacts or covenants. Unlike Hobbes, Althusius regards these social pacts not as the result of the egoistic interests of individuals, but as a result of human reciprocity. ${ }^{43}$ The pacts ought to articulate the pious and just spirit of God's covenant with human beings as manifested in the Decalogue. They are regulated by the lex consociationis et symbiosis (law of association and symbiosis), which is ultimately a natural law expressed in the Decalogue by the command to "honour their father and mother." ${ }^{4}$ This law establishes that there should be both ruling authorities and obedient subjects. ${ }^{45}$

Althusius also distinguishes between common and proper law. As already noted, common law (lex communis) depicts the unchanging moral law of God that is naturally implanted in the hearts of all people. ${ }^{46}$ The Decalogue and laws

40. Translation is from Carney, Politica, 17. For original Latin see Althusius, Politica, 1.1-2: "Politica est ars homines ad vitam socialem inter se constituem, colendam \& conservandum consociandi. Unde sum vocatur. Proposita igitur Politicae est consociatio, qua pacto expresso, vel tacito, symbiotici inter se invicem ad communicatium mutuam eorum, quae ad vitae socialis usum \& consortium sunt utilia \& necessaria, se obligant. Hominis politici symbiotici finis est sancta, justa, commoda \& felix symbiosis, \& vita nulla re necessaria vel utili indigens."

41. Althusius, Politica, 1.7.

42. Althusius, Politica, 1.8-10.

43. See Alain de Benoist, “The First Federalist: Johannes Althusius," Telos (2000): 25-58, 50.

44. Althusius, Politica, 1.10. Also see Witte, 182.

45. Witte, 183.

46. See Althusius, Politica, 1.11. Elazar, “The Multi-faceted Covenant," 201. 
of nations are visible forms of the invisible natural law that is already written on the hearts of everyone. ${ }^{47}$ Common law provides all people with a natural understanding of what constitutes just and unjust actions, fairness and unfairness, and binds the consciences of all people. ${ }^{48}$ Though implanted in the hearts of all people, the ius commune is not equally inscribed in the hearts of all people. ${ }^{49}$

Despite this, a collective understanding of the prescripts of God's natural law makes just social discourse possible. Althusius regards the Decalogue as the exemplary expression of the common law of nature for all peoples. Piety as the culmination of the first table of the Decalogue and justice as the governing principle of the second are, according to Althusius, the fundamental principles that infuse symbiotic life. If these principles are taken out of politics, all symbiosis and social life among people will be destroyed..$^{50}$ Piety and justice make symbiosis possible, and symbiosis makes possible a commonwealth that can communicate things. The Decalogue is thus proper to political science insofar as it animates symbiotic life. ${ }^{51}$ Since the Decalogue guides men to communicate things, services, and rights to their neighbours in a just manner, the magistrate is obliged to follow it. ${ }^{52} \mathrm{~A}$ fundamental feature of the ius communis is that government is held together by imperium and subjection. If order is to be preserved there have to be rulers and subjects. The rulers govern the functions of social life for the utility of subjects individually and collectively, while the subjects carry on their social lives according to the will of the superiors. ${ }^{53}$

Proper law, also called by Althusius individual law, is the law formulated on the basis of the common law and according to the special circumstances of a country. ${ }^{54}$ It thus corresponds in essence to the common law, but also diverges from common law as far as it addresses specific issues. ${ }^{55}$ Whereas common

47. Witte, 156.

48. Althusius, Selections from the Dicaelogicae, trans. Jeffrey J. Veenstra, Journal of Markets and Morality

9.2 (2006): 403-29, 440-41.

49. Althusius, Dicaeologicae, 442.

50. Althusius, Politica, 1.23 .

51. Althusius, Politica, 21.29, 41.

52. Althusius, Politica, 21.41.

53. Althusius, Politica, 1.12.

54. Althusius, Politica, 21.30.

55. Althusius, Dicaeologicae, 448. 
law is unchangeable, proper law is changeable and flexible. ${ }^{56}$ Proper laws differ from one institution to the next "according to the specie of each association" and can change with respect to circumstances. ${ }^{57}$ They are drawn up because not all people have a sufficient natural capacity to understand all the principles of natural law or to derive principles from common law. ${ }^{58}$ Another important feature of proper law is that it prescribes just punishments for crimes, whereas the common law only gives general commands. ${ }^{59}$

\section{The locus of sovereignty}

For Althusius only God Himself is sovereign in the ultimate sense of the word, while people possess a functional sovereignty within the framework of God's law. Legitimate power flows from God to the body of the universal association of the commonwealth who elect kings, princes, or optimates to exercise power on their behalf in accordance with the wishes of the commonwealth. ${ }^{60}$ Althusius thus vests political sovereignty in the community through their associations: "The owner and usufructuary of sovereignty is none other than the total people associated in one symbiotic body from many smaller associations." ${ }^{\prime 1}$

In Althusius's thought, subjects are individually under the rulers but collectively above them, while law is, properly speaking, superior to everyone. Everyone therefore needs to recognize law as something that is superior. ${ }^{62}$ Since law is superior to everything else, all power is limited by law and can never be regarded as absolute or eternal. In fact, any civil power can be terminated or abolished when a situation demands it. ${ }^{63}$ The body of people is always "prior to, more important than, and superior to its governors." ${ }^{64}$ Power, therefore, should

\section{Althusius, Dicaeologicae, 449.}

57. Althusius, Politica, 21.32.

58. Althusius, Politica, 21.32.

59. Grabill, Rediscovering the Natural Law, 148.

60. Althusius, Politica, 18.20 .

61. Carney, Politica, 13. For Latin text see Althusius's preface to the Politica on page 4: "Proprietarium vero \& usufructuarum majestatis, nulli alium, quam populu universum in corpus unum symbioticum ex pluribus minoribus consociationibus consociatum."

62. Althusius, Politica, 18.93.

63. Althusius, Politica, 18.106.

64. Althusius, Politica, 17.9 . 
be constantly exercised for the benefit of others, never for the sake of power itself. $^{65}$

Althusius's location of sovereignty in all members joined together indicates that he understands the people not as an array of individuals but as "the organised body of partial associations." ${ }^{\prime 6}$ Associations are moral entities with a corporate autonomy that express the unitary will of their symbiotes. ${ }^{67}$ This stands in stark contrast to the sovereignty doctrine of Bodin, which concentrates sovereignty in a single person and institution and ascribes absolute power to the state. It also differs from the hierarchical approach within medieval Roman law towards public associations. The Althusian model of sovereignty attempts to avoid state absolutism, while preserving the diverse civil composition of European society. ${ }^{68}$

\section{Private and public associations}

Althusius's construction of society is characterized by a system that Benoist terms as "growing complexity" ${ }^{69}$ Society is composed of various symbiotic communities that are gradually organized from bottom to top. The lower levels maintain their autonomy and sovereignty and limit the jurisdiction of the higher levels. ${ }^{70}$ Benoist rightly notes that "the autonomy of associations poses an insurmountable barrier to state power" in Althusius's thought. ${ }^{71}$

Concerning the nature of the symbiotic associations, Althusius distinguishes between the private associations of the family and the collegium and the public associations of the city, province, and commonwealth. Public associations cannot come into existence without the private associations that constitute them. ${ }^{72}$ Conversely, public associations are territorial in nature, while private associations are not. Whenever individuals enter larger associations,

\section{Althusius, Politica, 9.28.}

66. Hueglin, “Johannes Althusius," 35.

67. Benoist, 35.

68. Elazar, “The Multi-faceted Covenant," 203.

69. Benoist, 33.

70. Benoist, 33.

71. Benoist, 38 .

72. Elazar, “The Multi-faceted Covenant” 199. 
they do so as members of already existing communities, without giving up their rights in favour of the larger community. ${ }^{73}$

Each of these associations is established by a covenant and possesses its own sovereignty, vocation, and structure. The pact or covenant forms the foundation of all associations. It denotes much more than a contract or an agreement; it is a concept of living together in symbiosis through mutual assistance and benevolence. ${ }^{74}$ All five associations are rooted in necessity, yet their existence, form, and means of communication are determined by covenantal agreement. ${ }^{75}$ Althusius distinguishes between various phases of covenantal agreement, namely the agreement between the people themselves, the agreement between rulers and the people, the oath of the ruler to God, and lastly the pact between the rulers themselves to check and balance each other in order to prevent tyranny. ${ }^{76}$ Covenantal agreement entails that members associate with each other for the sake of a particular interest (quid peculiare) that serves what is necessary and useful for the symbiosis of their private lives. The bond (vinculum) is grounded in a trust that is granted and accepted by members in their communication of "mutual aid, counsel and rights." 77 The particular interest protected by the special covenant has the status of a symbiotic law (ius symbioticum) that corresponds with the nature of the association. This law entails that the individual members of the covenant are obliged to fulfil their duties within the association to the common benefit of all the members. ${ }^{78}$

Althusius defines the family as a natural association based on kinship and consent, while the collegium is a private civil organization that consists of three or more persons who have common interests and are brought together by necessity. ${ }^{79} \mathrm{He}$ defines two kinds of familial associations, namely the conjugal (conjugalis) relationship between husband and wife and the kinship relation that involves relatives and in-laws. ${ }^{80}$ The family is the most important social

\section{Benoist, 52.}

74. Hueglin, “Johannes Althusius," 21.

75. Elazar, “The Multi-faceted Covenant," 194.

76. See Witte, 191.

77. Althusius, Politica, 2.3.

78. Althusius, Politica, 2.5.

79. Althusius, Politica, 2.14, 4.1.

80. Althusius, Politica, 2.37. 
union and is the "seedbed" of all other symbiotic associations because it presents us with a miniature model for public associations. ${ }^{81}$ The collegium, in contrast with the family, is not a natural or permanent association but a civil, voluntary, and transitory association assembled to serve a common goal. ${ }^{82}$ It consists of people from the same vocation, profession, trade, craft, training, or persuasion who jointly profess a certain way of life as duty. ${ }^{83}$ When localized in towns and cities they function as guilds who serve private interests, but when extended to the provincial or commonwealth realms they are united into estates that primarily serve class interests. ${ }^{84}$ The collegium only serves the interests of its members and the needs of the commonwealth. ${ }^{85}$ The leader is elected by the common consent of the members and has coercive power over individual members but not the group as such, because power is ultimately vested in the group as a whole, not in an individual..$^{86}$ Rule is executed according to the internal laws and rights of the association as agreed upon, provided that such rule does not infringe upon the duties of the magistrate or the commonwealth's common law. ${ }^{87}$ In matters common to all, the majority of the assembled members bind the minority in their decisions. ${ }^{88}$

Althusius maintains that the family and collegium cannot be excluded from political life simply because they are private, since politics pertain to all symbiotic associations where things, services, and rights are communicated. ${ }^{89}$ Because all associations find their origins in symbiotic life, they have the same legitimacy and operate according to the same rules. ${ }^{90}$ Since public associations are compounds of the basic private associations in society, they do not exercise power over the lower levels.

81. Althusius, Politica, 2.14.

82. Althusius, Politica, 4.4-6.

83. Althusius, Politica, 4.5 .

84. Carney, Associational Theory, 77.

85. See Koch, 77.

86. Althusius, Politica, 4.6.

87. Althusius, Politica, 4.7, 12.

88. Althusius, Politica, 4.18 .

89. Althusius, Politica, 3.42.

90. See Benoist, 35. 
Althusius identifies three public associations-namely the city, province, and commonwealth (respublica). These public associations originate when many private associations are joined together in order to establish "an inclusive political order," which Althusius calls a politeuma. ${ }^{91}$ All three public associations are characterized by a separation of powers with a senate or council that represents the people through representatives from the private associations, and a chief executive who presides over the executive functions of the association. ${ }^{92}$

The politeuma (city) is an association composed of various families and collegia and formed by fixed laws within a particularly defined locality. ${ }^{93}$ The members of the politeuma consist of representatives (citizens) from the various private and diverse associations in the locality, not the individual members themselves. ${ }^{94}$ The private associations that make up the politeuma do not abandon their rights in favour of the politeuma, but maintain their individual status and autonomy. The superior is elected by the representatives; he directs the business of the city and governs to the benefit of the collective according to the mandate he receives from the community. As in the case of the collegium, the superior has coercive power over individuals, but not the citizens collectively. ${ }^{95}$ The superior is assisted by councillors and senators (representatives) who constitute a senatorial collegium and give him advice for the sake of the city's welfare. The leader of the senate is called a prefect who acts as an administrator of the commonwealth. Depending on the size of the city, the work of the prefect can be executed by more than one person. ${ }^{96}$ All officials are required to take an oath that they will perform their duties according to the community's laws, while individual citizens are required to take oaths of obedience. The politeuma is thus a "union confirmed by oath. ${ }^{97}$ The legal order (ius civitatis) of the city is determined by the common consent of its members, who are guided by the prerequisites for the effective communication of things, services, rights, and mutual concords..$^{98}$

91. Althusius, Politica, 5.1.

92. Elazar, “The Multi-faceted Covenant," 200.

93. Althusius, Politica, 5.8.

94. Althusius, Politica, 5.9.

95. Althusius, Politica, 5.10, 22.

96. Althusius, Politica, 5.49, 59.

97. See Koch, 79.

98. Althusius, Politica, 6.15. 
When it comes to the province, Althusius deviates from the logical structure of his thought, presumably to address the needs of his time. The ruler of the province is not elected by the members, nor is he accountable to the community as in the case of other associations, but to the magistrate and the ephors of the commonwealth. ${ }^{99}$ His administration, though, remains bound to the consent of the people, because the collective members always possess collective authority over their administrative head. ${ }^{100}$ The province consists of the various orders and estates (major collegia) within the locality of the province. ${ }^{101}$ These estates may be ecclesiastical or civil and have the responsibility to constitute by agreement the basic law of the province. ${ }^{102}$ The provincial head exercises care over provincial affairs by administering justice to individual persons, adjudicating court cases, and convening the various orders and estates to vote on matters that require decisions. When the orders have voted, the provincial head enacts those decisions into law. ${ }^{103}$

The commonwealth (politeia) is, according to Althusius, the most universal public association. It consists of cities, regions, and provinces that agree among themselves to constitute a single body and undertake by agreement to defend the "right of the realm" (ius regni) in their communication of things, services, aid, and counsel. ${ }^{104}$ As such it is a compound ${ }^{105}$ of many symbiotic associations:

It is a polity in the fullest sense, an imperium, realm, commonwealth, and people united in one body by the agreement of many symbiotic associations and particular bodies, and brought together under one right.

99. Carney, “Translators Introduction,” xix.

100. Hueglin, “Johannes Althusius," 36.

101. Althusius, Politica, 7.1.

102. Althusius, Politica, 8.4.

103. Althusius, Politica, 8.56 .

104. Althusius, Politica, 9.1.

105. Althusius's theory must not be confused with the Aristotelian scheme of subsidiarity that regards associations as parts of the state. In Althusius's thought the opposite is the case: the state is constructed out of other associations. See Henk Woldring, "The Constitutional State in the Political Philosophy of Johannes Althusius," European Journal of Law and Economics 5 (1998):123-32, 130. Also see M. R. R. Ossewaarde, "Three Rival Versions of Political Enquiry: Althusius and the Concept of Sphere Sovereignty," The Monist 90.1 (2007): 106-25. 
For families, cities, and provinces existed by nature prior to realms, and gave birth to them. ${ }^{106}$

The commonwealth (respublica, regnum, major consociatio) originates by people voluntarily associating themselves through common agreement so that they become a body with definite laws, establishing the necessary rights of the association and then entrusting the administration of these rights to elected officials, while subjecting themselves to the reign of the officials. ${ }^{107}$

As is the case with all associations, the sovereignty of the commonwealth is vested in the entire associated body of the realm, not a particular individual. ${ }^{108}$ This right of sovereignty, however, is not supreme, perpetual, or above law, but is subject to divine and natural law (lex naturalis et civilis). ${ }^{109}$ If the commonwealth enacts laws that depart from natural and divine law it cannot be considered as legitimate law. ${ }^{110}$ The commonwealth's law of sovereignty (right of the realm) is determined "by the purpose and scope of the universal association," which consists in ensuring a symbiotic human social life that serves the utility and advantage of the people. ${ }^{111}$

Althusius followed Calvin in describing the right of the commonwealth realm (ius regni) as both ecclesiastical and secular. ${ }^{112} \mathrm{He}$ regarded the communities of the state and church as sovereign spheres, each having their own responsibilities, yet standing in a symbiotic interdependent relationship. ${ }^{113}$ Both communities need the other for their proper functioning. ${ }^{114}$ Religion is

106. Carney, Politica, 66. For original Latin see Althusius, Politica, 9.3: "Politia, imperu, regnum, respublica, populus in corpus unum, consensu plurium consociationum symbioticarum, \& corporum specialium, seu corporum plurium consociatorum conjuntus, \& sub uno jure collectus. Nam familiae, civitates \& provinciae natura fua prius quam regna, quae ex hisce sunt oita, exstiterunt.”

107. Althusius, Politica, 9.5. It is important to note that rights are, in Althusius's thought, never transferred by the citizenry to rulers, but always remain the property of the citizenry who entrust elected officials with the preservation of their rights.

108. Althusius, Politica, 9.18 .

109. Althusius, Politica, 9.20.

110. Althusius, Politica, 9.9.

111. Althusius, Politica, 9.25.

112. Von Gierke, 60.

113. See Ossewaarde, 118.

114. Carney, Associational Theory, 129. 
responsible for the welfare of the soul, while government is responsible for the welfare of its people's material needs (the body). ${ }^{115}$ The government of the soul is regulated by the first table of the Decalogue's principle of piety, while the government of the body is directed by the second table of the Decalogue's principle of justice. ${ }^{116}$ True and pure religion can never be established by a majority vote, but it is determined by the Word of God and exercised by the church, while the magistrate is responsible for the protection of the true faith. ${ }^{117}$ True to his Calvinist background, Althusius provides for a kind of religious covenant between God and the commonwealth that explicates the duties of magistrate and clergy in the administration of the church. The magistrate is the defender of faith. His duty towards ecclesiastical administration lies in the public protection of true worship, establishing ecclesiastical courts, validating orthodox canons of faith, convening church assemblies, electing presbyteries in every district with consent from the church, and overseeing processes of minister legitimation. ${ }^{118}$ However, the administration of ecclesiastical offices belongs to the clergy. Ultimately, in his administration of ecclesiastical affairs the magistrate cannot do anything without "the counsel and consent of the clergy based on the Word of God." 119

The secular administration of the commonwealth pertains to the relationships between citizens and thus gives expression to the demands of the second table of the Decalogue. The lex moralis of the Decalogue needs to be adapted to the varying circumstances of the commonwealth through the promulgation of laws. These laws may either add or take away from the moral law, but may never contradict God's natural law (ius naturalis) or moral equity. ${ }^{120}$

The various cities, provinces, and regions within the commonwealth are represented by delegates who serve in a general council within the associated body of the commonwealth. They meet to discuss the best interests of the commonwealth and provide remedies for particular evils. All public affairs are

115. Althusius, Politica, 9.33

116. Althusius, Politica, 9.28.

117. Althusius, Politica, 9.28. Althusius allowed for religious tolerance to a limited degree. Different religious persuasions can be tolerated, but they must be suppressed when they openly attack the true faith. 118. Althusius, Politica, 18.27-31.

119. Althusius, Politica, 18.4 .

120. Althusius, Politica, 10.8 . 
referred to the council, and after examination and discussion are decided by a majority vote. ${ }^{121} \mathrm{~A}$ majority vote is only applicable to issues affecting all members. If an issue concerns only a certain group of people, this group has a right to veto the decision of the Council. This once again emphasizes the consensual form of Althusius's political philosophy. Unity can only be achieved if the plural dynamics of a society are taken into account and if such groups are awarded autonomy in matters that directly and exclusively relate to them.

Althusius held that issues pertaining to various groups that cannot be solved by general vote ought to remain on the lower levels. ${ }^{122}$ This approach was typical of the Calvinist view of church government that originated from the Synods of Wesel (1568) and Emden (1571) onwards and which maintained that higher assemblies can only discuss matters that cannot be solved in lower church assemblies.

Althusius posits that the administration of the commonwealth should be undertaken by ephors and the supreme magistrate. The ephors are representatives of the commonwealth elected by the votes of members of the entire realm who together form a collegium that will "administer, govern and conserve the body and rights of the universal association." ${ }^{123}$ The collegium of ephors elects the supreme magistrate and assists him with aid and counsel in executing his task as the leader of the commonwealth. The covenant by which the ephors constitute the magistrate entails committing the realm and its administration to the supreme magistrate and promising the obedience and compliance of the people. ${ }^{124}$ The ephors have the duty to subject the magistrate to the law and may even restrain and impede his authority if he undertakes actions that transcends the limits of his office. ${ }^{125}$ If the magistrate becomes tyrannical ${ }^{126}$ they may remove him and undertake the administration until a new magistrate is elected. ${ }^{127}$

121. Althusius, Politica, 33.12.

122. Thomas Hueglin, Early Modern Concepts for a Late Modern World: Althusius on Community and Federalism (Waterloo, ON: Wilfrid Laurier University Press, 2008), kindle edition, loc. 2617 [Johannes Althusius (1557-1638)].

123. Althusius, Politica, 18.3.

124. Althusius, Politica, 17.62 .

125. Althusius, Politica, 18.48 .

126. Tyrannical behaviour is where the magistrate overthrows the fundamental laws of the commonwealth or acts in a spirit contrary to piety and justice. See Althusius, Politica, 18.63.

127. Althusius, Politica, 18.63 . 
As such they possess more power and authority than the supreme magistrate. Notwithstanding their special authority, the ephors never take ownership of the association's rights, nor are they superior to the rights of the commonwealth. The rights always remain under the control of the universal association. ${ }^{128}$ Thus, by distributing power among many, Althusius attempts to prevent power abuse: "Power is more useful when deployed among a large number, and the affairs of the commonwealth are more readily expedited when communicated among many." 129

\section{The relevance of Althusius's political philosophy for a postmodern society}

Althusius constructed his system within a time and context very different from ours. We therefore cannot translate the political principles that he applied to a medieval society in the same exact manner to postmodern societies. For instance, the Calvinist model of religious homogeneity cannot be enforced on modern secular states, nor can the state be a compound of private and public associations. Modern societies are simply too complex. Yet, it would be a mistake to study Althusius purely from a historical point of view as a transitional figure in the history of political philosophy. The principles that underlie his political philosophy are, in my view, a source of great import for our highly diverse postmodern societies.

A first important element in Althusius's thought is his recognition of pluralism and diversification as not only a fact of life but an essential part of the created order that needs to be taken seriously in political discourse. Skillen rightly notes that the "reluctant admittance of degrees of pluralism in most Western societies has come about as a result of political pressures, pragmatic accommodation and arguments of raisons détat." ${ }^{130}$ What is needed is a coherent social philosophy that provides a substantial foundation for a politics that is able to deal with the reality of pluralism. Althusius's symbiotic theory provides an important point of orientation for reflection on this topic. He understands not only the importance of association in human life but also the

128. Althusius, Politica, 18.83 .

129. Carney, Politica, 105. For the original Latin see Althusius, Politica, 18.72: "Sic enim potestas a pluribus explicata, \& negotia in Rep. multis communicata, facilius expediuntur."

130. James Skillen, "From Covenant of Grace to Equitable Public Pluralism: The Dutch Calvinist Contribution," Calvin Theological Journal 31 (96): 67-96, 92. 
diverse natures of associations that are manifested in various species of association with their own unique laws that govern their functions. For Althusius, plurality is an important prerequisite for symbiosis because plurality makes organic interdependency and mutual assistance possible. Because associations cannot flourish without each other, associations are not hierarchically related to each other and the legal competence of one association cannot be extended over others. ${ }^{131}$

The significant contribution of Althusius's political philosophy is located in the fact that he constructed a political model on the principle of symbiosis, as opposed to methodological individualism. Althusius used the concept of symbiosis to indicate how the organization of plural forms of community can serve unity of action in a society. The political models of most contemporary Western societies emanate from methodological individualism and are built on the idea that the state is primarily a collection of autonomous individuals, not groups. Because of this individualist premise, the majority of Western societies reject the explicit constitutional protection of collective rights or group rights since they argue either that groups cannot possess subjective juridical rights or that the protection of individual rights inevitably protects groups. ${ }^{132}$ As a result, little public space is allowed for intergenerational groups with a legal and political status that act as intermediaries between individuals and the state. This unrestrained individualism that bypasses the importance of symbiosis contributes to the gradual deformation of social institutions in Western societies and often leads to the exclusion of minority, religious, language, and cultural groups from public spaces. ${ }^{133}$

\section{See Woldring, 129 and Ossewaarde, 117.}

132. The South African Constitution that was enacted in 1996 is generally regarded as a model liberal constitution. In the process leading up to the drafting of the Constitution, the protection of group rights in a Bill of Rights was considered. Eventually the Constitutional Assembly decided against incorporating group rights into the Constitution because groups supposedly do not possess juridical subjectivity, group rights are difficult to adjudicate, and the protection of individual rights will inevitably lead to the protection of group rights. For a detailed discussion on the topic see Nico Vorster, Kerk en menseregte binne ' $n$ regstaat (Potchefstroom: PTP, 2003), 158-65.

133. See Jakobus Marthinus Vorster, “Banning the Burka: An Ethical Appraisal," Journal of Reformed Theology 5 (2011): 86-103, for a discussion on the systematic exclusion of religious groups from public spaces in France, Singapore, and Turkey through legislation that prohibits public religious expressions such as the wearing of burkas. 
The Althusian model of unity of action through plural organization provides an important balance to the relentless individualism of Western politics. Althusius's symbiotic political theory awards both private and public associations a political status, while rejecting the distinction between a public state and private society, because no association "can claim to be exempt from political conduct." 134 This stands in stark contrast to classical liberalism's understanding of political society as a collection of isolated individuals. ${ }^{135}$ Elazar rightly notes that though the constitutional protection of individual rights is of fundamental importance for the maintenance of peaceful and democratic societies, "groups are also to be recognised as real, legitimate and requiring an appropriate status." 136

The concept of symbiosis signifies association as a fundamental natural right driven by both necessity and volition. The human being is, after all, by nature an associational being that cannot function without relationships. The right to associate in religious, cultural, language, and other groups is as fundamental to human nature as the individual rights to life, dignity, equal treatment, and freedom. Symbiotic theory, thus, depicts associations as real and legitimate entities. Since social pacts develop from necessity and volition, various rights and duties originate that should be awarded an appropriate legal and political status, not only for the reason that they emanate from the basic and inalienable natural right to association, but also because they are important for social cohesion.

When groups are excluded from public spaces, important individual rights frequently lose practical import, because individuals generally express their interests and exercise their rights through groups. Intermediate groups with a recognized public status are needed to limit state power and mediate individual rights. In most democratic societies, public associations indeed have the right to express their views in public and even have the luxury of making submissions when new concepts of legislation are drawn up. Yet, their influence on these processes is severely limited because they do not possess coercive political or legal power. Often public participation in legislative processes is only

134. Hueglin, Classical Debates for the 21st Century, kindle edition, loc. 2669, 2674 [Johannes Althusius (1557-1638)].

135. See Patrick Riley, “Three $17^{\text {th }}$ Century Theorists of Federalism: Althusius, Hugo and Leibniz," Publius 6.3 (Summer, 1976): 7-41, 16. Also see Benoist, 50.

136. Elazar, "Althusius' Grand Design for a Federal Commonwealth," xl. 
symbolic in nature and has little impact on the eventual outcome of legislation. In South Africa, for instance, public participation in the drafting of new laws on press freedom in 2012 could not prevent draconian limitations on press freedom from being enacted into law-despite vehement protest from civil society.

In contrast to contemporary political discourse, private and public associations possess coercive legislative and political power in Althusius's political system. This enables individuals to participate directly in the polity through their associational groups in a manner that is truly transformative in nature, not merely symbolic. How public associations are to participate directly in a democracy depends on the political context and social composition of a society. Althusius applied his views to a seventeenth-century political context by creating a federal type of political system that makes the commonwealth an entity constructed of various other associations. In contemporary politics, other practical ways can be found to extend the political participation of groups in public life. One possible avenue is to think about the possibility of creating what could be called civil society democracies. In fact, this kind of democracy is already developing spontaneously around the world and is a natural product of the logic of participatory democracy that underlies the concept of a constitutional democracy. A civil society democracy creates multiple avenues for political participation. It allows grassroots citizens to participate in public debates and legislative processes, enables citizens to determine their own affairs as far as possible, and limits the role of the state in society. In order to create such a democracy, social movements or groups have to be created and strengthened to enhance civil engagement and to act as intermediaries between the state and people at the grassroots level. Importantly, these groups within civil society should be awarded some kind of formal political power to prevent their participation in political processes from being purely symbolic or advisory in nature. Moreover, consensual politics ought to be promoted by allowing such groups to enjoy as much as possible autonomy in their own affairs, provided that neither the common good nor other associations are negatively affected by their actions.

A second important feature of Althusius's political philosophy is his understanding of politics as sharing that encourages consensual deliberation. In contrast to classical liberalism's mechanical division of various spheres of life, Althusius's symbiotic theory understands civil society as symbiotically intertwined and interwoven with each other through processes of sharing and 
mutual aid. Symbiotes are all dependent on one another in order to function well. In a world where hegemony is no longer a viable option, politics needs to concentrate on accommodating different beliefs through plural forms of governance that are guided by processes of sharing and mutual agreement. ${ }^{137}$ Whereas classical liberalism is primarily concerned with the setting of constitutional boundaries to protect the individual against external coercion, Althusian liberty is positively aimed at empowering the individual to participate with fellow symbiotes in the socio-political processes of the commonwealth. ${ }^{138}$ Thomas Hueglin rightly notes that in Althusian thought politics is not about "a problem of power and governmental authority, but of mutual help, non-aggression, cooperation and trust." ${ }^{139}$ This constructive understanding of politics provides an important alternative to the conflict driven politics so prevalent in many societies that often degenerate into adversarial litigation; this approach might help to lessen the current conflict in Western societies between the sacred and profane spheres. Setting boundaries by marginalizing religion from the public sphere will not solve the current crisis. The best way to manage diversity and prevent radicalism from spiralling out of control is to promote consensual politics by allowing public space for all groups in society and to provide them with as much autonomy in their own affairs as possible. Obviously, the right of such groups to express their views in public is not unlimited but is accompanied by the responsibility not to coerce, stereotype, or endanger citizens who do not share their particular views.

Third, the emphasis in Althusian thought on mutual aid to the common benefit of all provides us with a possible resource to promote social equality. The ideal of equality inevitably entails that positive actions be taken to achieve it. If politics is about mutual aid, cooperation, and the utilization of the diversity of gifts in a society, it becomes a social tool for achieving equality. Moreover, in contrast to neo-liberalism's aggressive philosophy of progression through competition, progression in a society is attained, according to symbiotic theory, by a general participation in social processes, benevolence, aid, and the utilization of human gifts to the benefit of all. The more symbiotic a society, the greater the possibility for social equality. 
Lastly, Althusius provides us with important tools to limit power. By defining government not as an end in itself, but as an instrument that serves the "social purpose of life," Althusius reframes the concept and purpose of power. ${ }^{140}$ His theory truly vests power in the people as a whole, while the ius regni is situated in the pact of the realm. By distributing power among many and encouraging a system that is based on a deliberating and consensus kind of politics, Althusian theory creates various barriers to the excessive exercise of powers. Most importantly, sovereign power is limited by allowing lower level groups to maintain their sovereignty and to participate in public life.

\section{Conclusion}

Witte ${ }^{141}$ rightly notes that Althusius "aspired to create from Calvinist premises a universal, legal, political and social theory that would appeal not just to fellow Calvinists but to all people of good faith and good will." Althusius's main contribution to Dutch constitutionalism was that he developed a system that attempted to safeguard the sovereignty of local associations within the ambit of the sovereign nation-state. In doing so, he not only provided a system containing various checks and balances against the abuse of power, he also presented a theory that might be useful to solve the plurality/unity conundrum in contemporary postmodern societies. His system is useful in that it constructs a political theory based on symbiosis, as opposed to the exclusively methodological individualism of classical liberalism. Althusius also awards both private and public associations a public and legal status, thus utilizing them as intermediaries between the interests of the state and of individuals. His understanding of plurality and diversity as essential prerequisites for a viable society is of great importance for societies that struggle to come to terms with hyperpluralism. Moreover, the Althusian notions of politics as sharing, non-aggression, trust, agreement, benevolence, and mutual aid provide an interesting alternative to contemporary power politics, as well as a possible remedy to address social inequality. Lastly, by vesting power in the people as a whole through their associations, Althusius provides us with an additional tool to limit state power.

140. Hueglin, “Johannes Althusius," 26.

141. Witte, 206. 